\title{
Challenges in using fish communities for assessing the ecological integrity of non-perennial rivers
}

\author{
MF Avenant* \\ Centre for Environmental Management, University of the Free State, Bloemfontein 9300, South Africa
}

\begin{abstract}
Environmental Water Assessments (EWAs) aim to protect the ecological integrity of rivers amidst increasing anthropogenic pressures on freshwater resources, and fish communities are the ecosystem component most commonly included. The Fish Response Assessment Index (FRAI) was developed to assess the integrity of fish communities in South African rivers and is commonly applied in EWA studies. This paper reports on the suitability of the FRAI for the non-perennial Seekoei River and discusses some of the challenges faced. Our relatively long and thorough study on the Seekoei River confirmed the concerns that earlier, snapshot, fish integrity assessments in the Orange River system raised: that the existing fish indices are not ideally suited for these rivers with their naturally low species richness and hardy, generalist fish communities. Other difficulties with the use of a score-based method include prediction of the expected species, calculation of a frequency of occurrence rating, selection of the right sampling times for comparative purposes, loss of habitats and sampling points under different flow conditions, and problems experienced when using accumulated data to try to correct for a situation of having too few sampling points. At this stage a more generalised approach is suggested for the Seekoei River, and ultimately other similar non-perennial systems. This could include a number of community characteristics, such as abundance, species richness, species diversity and evenness, recruitment, fish health and the presence/absence of exotic species.
\end{abstract}

\section{Introduction}

The environmental water requirements of the fish community of the Seekoei River, an ephemeral southern tributary of the Orange River, South Africa, were assessed as part of a larger Water Research Commission-funded research programme. The aim of the programme was twofold: to investigate the suitability of existing EWA methods used on perennial rivers for use in non-perennial rivers, and to develop a methodology for determining environmental water requirements for these systems.

Environmental Water Assessments (EWAs) aim to protect the ecological integrity of rivers under increasing anthropogenic pressures, by trying to predict how much water can be harvested from a river without causing ecological damage (Pusey, 1998). In order to predict how much water can be harvested, the quantity of water needed to maintain river integrity in a particular state, often referred to as the ecological Reserve, needs to be known (Acreman and Dunbar, 2004). In South Africa, the determination of the ecological Reserve is required by law (National Water Act, No. 36 of 1998 (NWA)) before water use licences may be issued. This implies the necessity to develop appropriate methodologies to give effect to the legislative requirements.

Historically, fish were the centrepiece of most EWAs (also referred to as instream flow assessments (IFRs); Arthington et al., 2003). The earliest EWAs were designed to protect the habitat required by particular fish species of recreational or commercial value; e.g. the Montana method which predicted the ecological condition of a river on the basis of the relationship between the percentage of flow in a river (MAR) and the quality of its instream fish habitat (Tennant, 1976). With the

\footnotetext{
* To whom all correspondence should be addressed.

용 +27(51) 401-3939; fax: +27(51) 401-2629;

e-mail: avenantmf@ufs.ac.za

Received 2 October 2009; accepted in revised form 31 May 2010.
}

development of the holistic methodologies in the 1990s, the emphasis has moved away from preserving only certain valued species to the protection of entire river ecosystems. Three holistic methodologies have been developed for perennial rivers in Southern Africa: the Building Block Methodology (BBM; King et al., 2000; Tharme and King, 1998), the Downstream Response to Imposed Flow Transformations (DRIFT) method (King et al., 2003; Brown and King, 2000) and the Flow StressResponse Method (FSR; O'Keeffe et al., 2002). These holistic methodologies consider a range of biophysical river components: hydrology, geomorphology, physic-chemical characteristics, fish, aquatic invertebrates and riparian vegetation.

In South Africa, EWA methods are applied within the context of a Reserve determination process, in order to comply with the legal requirements for determining the Reserve (see Fig. 1). In essence, a variety of tools can be applied to inform two important processes within this context: the determination of the Ecological Categories for present and future conditions (also referred to as EcoClassification; see Step 3 of the Reserve process) and the determination of the environmental water requirements with regards to both quality and quantity (Step 4 of the Reserve process) (Louw, 2004). The main objective of the EcoClassification process is to create an understanding of the present ecological state (PES), or integrity, of a river, in order to set attainable ecological objectives for the future management of the river (Kleynhans and Louw, 2008). As part of the EcoClassification process, the PES of each of the biophysical river components is determined and described in terms of ecological categories, where a Category A represents close to natural conditions and a Category F represents a criticallymodified condition. Methods to guide the determination of the PES for each of the components are in various phases of development (Kleynhans and Louw, 2008). The method most often used to determine the PES of fish communities is the Fish Response Assessment Index (FRAI; Kleynhans, 2008a), an extension of the earlier Fish Assemblage Integrity Index (Kleynhans, 1999). 


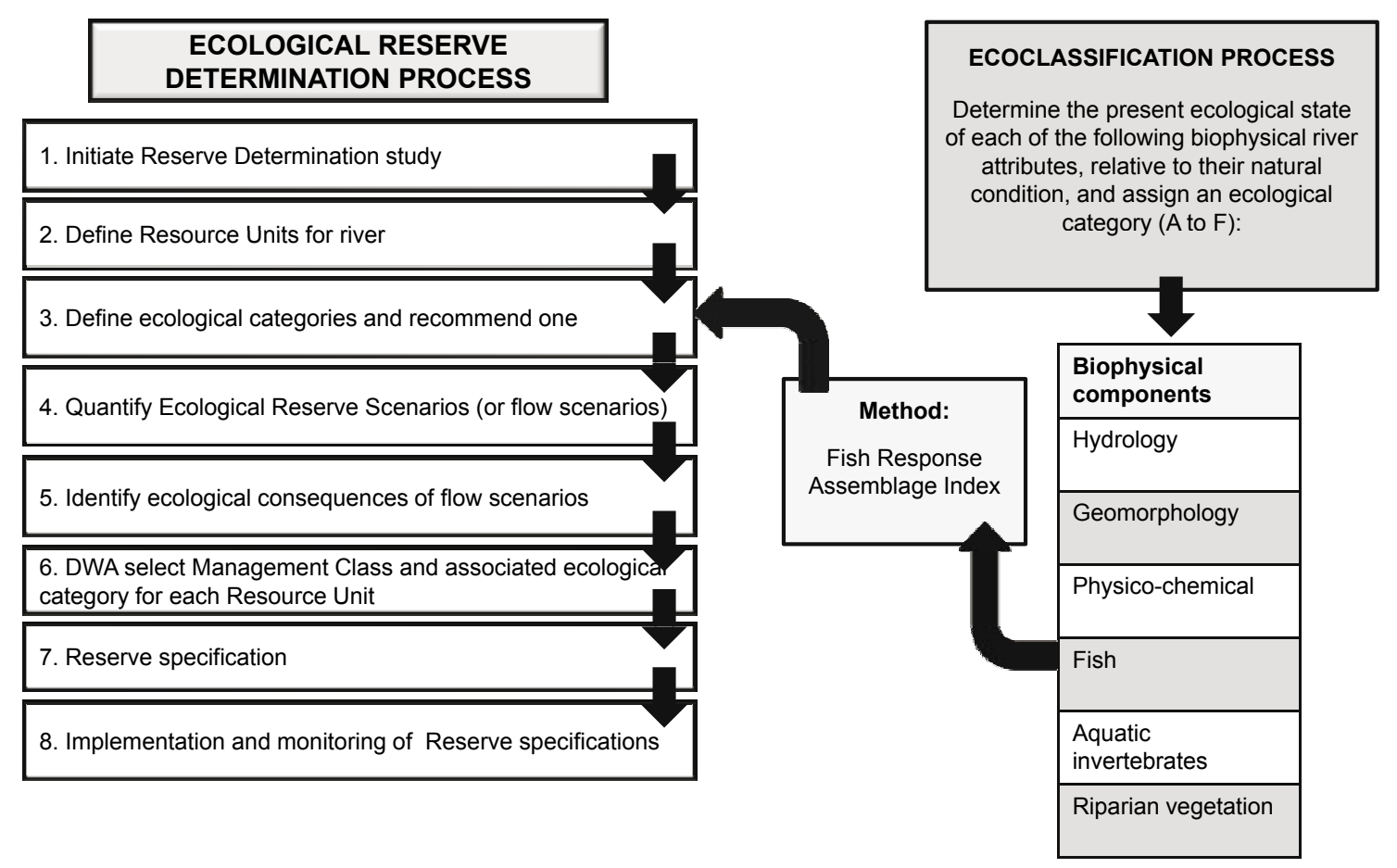

Figure 1

Diagram showing the South African Reserve Determination process and the point of input for results from the EcoClassification process (adapted from Louw and Hughes, 2002)

The FRAI is an assessment index based on the environmental intolerances and preferences of the reference fish assemblage, and the response of the constituent species of the assemblage to particular groups of environmental determinants or drivers (see Kleynhans, 2008a for a detailed description of the method). It therefore aims to measure (and interpret) how a fish assemblage responds to habitat changes as a result of changes to the driving components (in this case the geomorphology, hydrology and physical and chemical properties) in a river reach. The assessment of the species' response to changing environmental conditions can be done either by fish surveys or inferred from changing environmental conditions. Information on the life-history strategies and habitat preferences and requirements of most South African freshwater fish species have been captured in an expert-knowledge database (Kleynhans, 2003) which was built into the FRAI model. Habitat features are evaluated in terms of their suitability for the species constituting the assemblage (Kleynhans, 2008a).

This study investigated the suitability of the FRAI for the Seekoei River. It alerts fish specialists to specific challenges faced with the application of the index in non-perennial rivers in the Orange-Vaal system. Some comments are made towards finding a more suitable method for assessing the integrity of fish communities in these rivers.

\section{Study area}

The Seekoei River was selected for its reliable flow record (allowing for hydrological modelling) and relative closeness to Bloemfontein (allowing frequent access to the river). The Seekoei River, a southern tributary of the Orange River, is situated in the Level II Nama Karoo ecoregion (26.03; Kleynhans et al., 2004) between 1300 and $1700 \mathrm{~m}$ a.s.l. in the dry central parts of South Africa (Fig. 2). The landscape is dominated by flat-lying Karoo Supergroup sediments that have been intruded

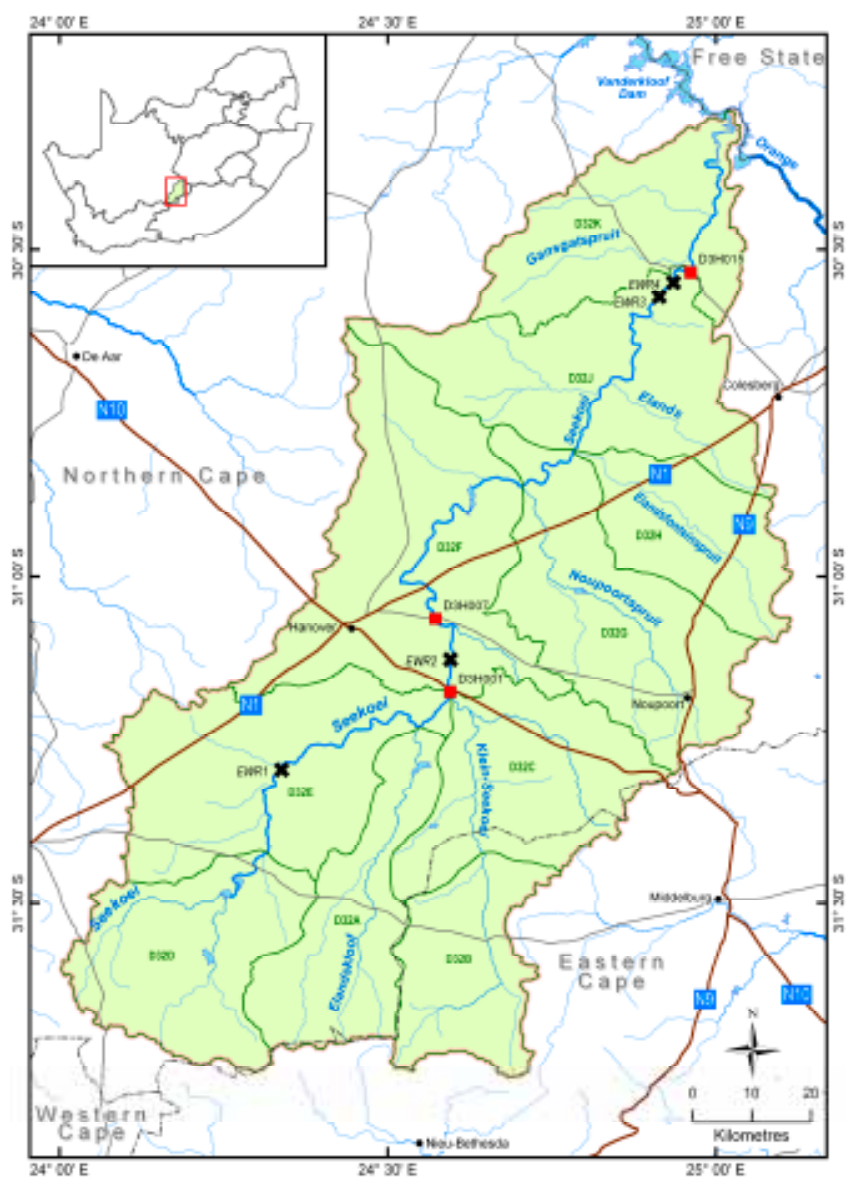

Figure 2

Seekoei River catchment. The location of the 4 sampling sites and the gauging weirs used for analyses is shown. 


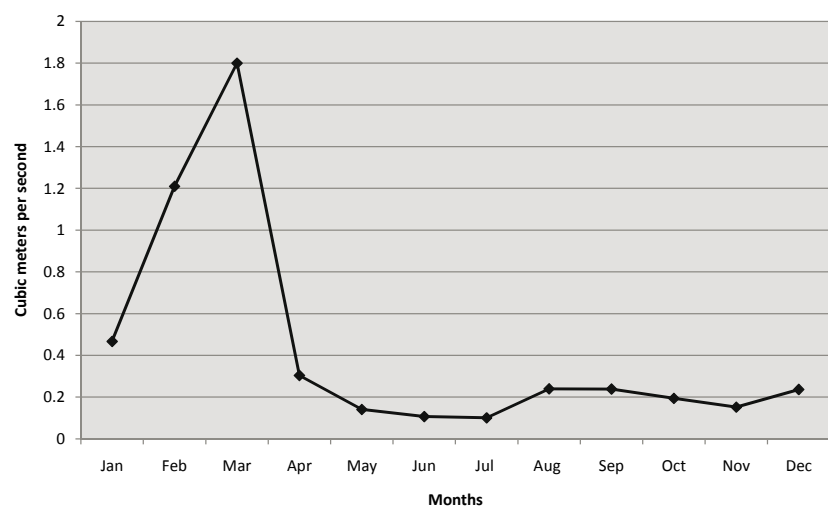

Figure 3

Mean monthly stream discharge (in m3/s) at the D3H015 gauging station for the period 1980 to 2005 (adapted from Steÿn, 2005)

by sills and dykes of dolerite (Dollar, 2005). The topography is therefore mostly flat with steeper slopes only occurring closer to the catchment's boundaries, as well as in an isolated area in the lower part of the catchment (quaternary catchment D32J) where the river passes through a gorge.

The catchment experiences large fluctuations in both diurnal and seasonal temperatures, with mean maximum summer temperatures in January above $30^{\circ} \mathrm{C}$ and mean minimum winter temperatures below $1^{\circ} \mathrm{C}$ (Schultz, 1980). Frost occurs frequently between May and October (average $158 \mathrm{~d} / \mathrm{yr}$; Venter et al., 1986). The catchment receives mostly summer rainfall (October to March) with the mean annual rainfall ranging between 250 and $400 \mathrm{~mm}$ (Schulze, 1997). Rainfall could, however, be highly variable - not only between years, but also between months (Hughes, 2008a). Evaporation varies between $1900 \mathrm{~mm}$ in the high-lying areas and $2500 \mathrm{~mm}$ in the northwestern parts of the catchment (Schulze, 1997). The potential mean annual evaporation (average of $1911 \mathrm{~mm} / \mathrm{yr}$ ) within the catchment exceeds the potential mean annual precipitation (average of $313 \mathrm{~mm} / \mathrm{yr}$ ) by 6 times, resulting in a low gross mean annual runoff (MAR) and a high coefficient of variation in MAR (Dollar, 2005).

Gauge records from flow-measurement weir D3H015 (located at the outlet of quaternary catchment D32J) indicate that the Seekoei River experiences surface flow for approximately $45 \%$ of the time (Steÿn, 2005). Mean monthly stream discharge is highest in late summer (February-March) and lowest in winter (May-July; see Fig. 3). During the study, however, it became evident that these flow characteristics were only relevant to the $8 \mathrm{~km}$ immediately upstream of the flowmeasurement weir; the upstream channels experience flow less than $10 \%$ of the time. Most of the flow recorded at the measuring-weir was therefore generated in the high topography gorge area in the lower part of the catchment (Hughes, 2008b). This area covers only a small area of the total catchment, but has a major influence on the flow regime (Hughes, 2008a). Due to concentrated outflow at the base of a perched aquifer and/or distributed lateral flow, the lower Seekoei River experiences prolonged flow after rainfall events (Hughes, 2008a). In the drier upper and middle parts of the catchment, persisting pools are sustained by contributions through connections with groundwater (Van Tonder et al., 2007).

The Seekoei River is situated in a rural area. A large number of dams and weirs have been erected in the river course for irrigation abstraction, stock watering and recreation, and the river's instream and riparian habitats are considered to be moderately modified, mainly due to flow regulation and modification (Watson and Barker, 2006). No major towns draw water from, or discharge water into, the river. The socio-economic profile of the population utilising the Seekoei River is made up of established commercial farmers and their staff. General farming activities are game and stock farming, or a combination of livestock, game and limited opportunistic irrigation agriculture.

\section{Methods}

The selection of the sampling sites and the frequency of sampling were influenced by the requirements of the other disciplines which were also part of the wider multi-disciplinary study, namely, hydrology, geohydrology, catchment and fluvial geomorphology, physical and chemical water quality, riparian vegetation, aquatic macroinvertebrates, and socio-economics. To apply the FRAI model to the acquired fish data, the 8 steps outlined in Kleynhans (2008a) were followed.

As a $1^{\text {st }}$ step, the river was delineated into 5 geomorphologically-distinct sections, or macro-reaches, based on its longitudinal profile (see Dollar, 2005) and information provided by an aerial survey (see Table 1 for a summary).

In a $2^{\text {nd }} \mathbf{s t e p}$, a list of reference fish species was compiled for each river section. As fish data were mostly lacking for

\begin{tabular}{|c|c|c|c|c|c|c|}
\hline \multicolumn{7}{|c|}{$\begin{array}{c}\text { Table } 1 \\
\begin{array}{l}\text { A summary of the macro-reaches for the Seekoei River main stem } \\
\text { (adapted from Dollar, } 2005 \text { and Watson and Barker, 2006) }\end{array}\end{array}$} \\
\hline $\begin{array}{l}\text { Macro- } \\
\text { reach }\end{array}$ & \begin{tabular}{|l} 
Length \\
$(\mathrm{km})$
\end{tabular} & m. a.s. I. & $\begin{array}{l}\text { Slope } \\
(\mathrm{m} / \mathrm{m})\end{array}$ & Dominant channel type & Lithology & Major impacts \\
\hline 1 & 15.3 & 1855 & 0.01905 & Floodouts & $\begin{array}{l}\text { Dolerite, alluvium over } \\
\text { mudstone and sandstone }\end{array}$ & Unknown \\
\hline 2 & 8.5 & 1595 & 0.00465 & $\begin{array}{l}\text { Isolated pools and dry } \\
\text { distributary channels }\end{array}$ & $\begin{array}{l}\text { Alluvium over mudstone } \\
\text { and sandstone }\end{array}$ & $\begin{array}{l}\text { Flow regulation due to in-channel } \\
\text { structures }\end{array}$ \\
\hline 3 & 33.1 & 1538 & 0.00278 & $\begin{array}{l}\text { Isolated pools and dry } \\
\text { distributary channels }\end{array}$ & $\begin{array}{l}\text { Alluvium over mudstone } \\
\text { and sandstone }\end{array}$ & $\begin{array}{l}\text { Flow regulation due to in-channel } \\
\text { structures }\end{array}$ \\
\hline 4 & 144.1 & 1477 & 0.00134 & $\begin{array}{l}\text { Single thread channel } \\
\text { and pools }\end{array}$ & $\begin{array}{l}\text { Alluvium over mudstone } \\
\text { and sandstone }\end{array}$ & $\begin{array}{l}\text { Flow modification and regulation due } \\
\text { to reed encroachment and in-channel } \\
\text { structures }\end{array}$ \\
\hline 5 & 62.3 & 1260 & 0.00203 & Pool/riffle/rapid & $\begin{array}{l}\text { Dolerite and shale, silt- } \\
\text { stone and sandstone }\end{array}$ & $\begin{array}{l}\text { Flow modification and regulation due } \\
\text { to reed encroachment, weirs and the } \\
\text { Vanderkloof Dam }\end{array}$ \\
\hline
\end{tabular}


the Seekoei River, the reference fish assemblages were mainly based on historical records for the Orange River, Vanderkloof Dam (situated at the confluence of the Seekoei and Orange rivers) and other southern tributaries of the Orange River situated in the same Level II ecoregion (Kleynhans, 2008a). Literature sources consulted included, for example, Jubb (1964; 1967; 1972), Van Schoor (1972), Gaigher et al. (1980), Skelton and Cambray (1981), Hocutt and Skelton (1983), Cambray and Bruton (1984), Tómasson et al. (1984), Skelton (1986; 2001), Benade (1993), SAIAB (2006), and correspondence with Cambray (2006), Benade (2006), Venter (2005), Clarke (2005), Bishop (2005) and Niewoudt (2005). The fish habitat and cover available for each river section were also taken into account, relying on expert judgement and the team's previous experience of working in the Orange River system.

As a $3^{\text {rd }}$ step, the habitat integrity of the instream river channel and riparian zone was assessed for each river section according to the method of Kleynhans (1996) and Kleynhans and Hill (1999; see Watson and Barker, 2006), in order to provide information on the present condition of fish habitat in the river. Additional information on the present state of the river's physical drivers, namely, the hydrology, geomorphology and physical and chemical characteristics, was obtained from the respective specialists involved in the wider project. This information was later used to interpret fish response.

As a $4^{\text {th }}$ step, representative sampling sites were selected in 3 of the 5 river sections. Four sites (EWR1 to EWR4) were selected in the upper, middle and lower reaches of the river (see Fig. 2).

EWR1 is situated in Macro-reach 3 in the upper Seekoei River (Table 2). Surface flow occurs infrequently in this section of the river, i.e for only an estimated 2 to $3 \%$ of the time (Hughes, 2008b). The site is dominated by a persistent, but isolated, pool, of approximately $90 \mathrm{~m}$ long, $7.4 \mathrm{~m}$ wide and approximately $80 \mathrm{~cm}$ deep at the deepest point. The pool's substrate consists mostly of sand covered by organic matter deposits. The pool is fringed by sedges and the active channel is overgrown with sedges.

EWR2, which is located in the middle Seekoei River, experiences surface flow for less than $5 \%$ of the time (Hughes, 2008b). Sampling was done in a large isolated pool (approximate length $75 \mathrm{~m}$; maximum width $12.9 \mathrm{~m}$ ) surrounded by reeds (Phragmites australis). The pool has a shallower section $(<50 \mathrm{~cm})$ of about $30 \mathrm{~m}$ long, which dried up once during the 2 -year study period. The pool has a sandy bottom with decomposing reed material.

EWR3 and EWR4 are both situated in the gorge area of the lower Seekoei River (Table 2). Both these sites experience more frequent surface flow and have more complex habitats than the
2 upstream sites. Available habitat at EWR 3 comprises a large pool (1 $173 \mathrm{~m}$ long, 100-180 $\mathrm{m}$ wide, and a maximum depth of $236 \mathrm{~cm}$ ) and, when the river is flowing, a run of $30 \mathrm{~m}$ and a riffle/rapid of about $70 \mathrm{~m}$ long. The bottom of the pool consists mostly of coarse to fine sand, while the bed material of the run and riffle/rapid is typically coarser, consisting of cobbles and boulders. The marginal vegetation consists mostly of reeds and sedges. At EWR4 sampling was conducted in a large pool with a sandy, gravel bottom. Several bedrock pools and a riffle were additionally sampled when the river was flowing. Marginal vegetation at the site comprised mostly reeds with indigenous trees on the river banks.

During the $\mathbf{5}^{\text {th }}$ step the habitat potentially available to fish at each sampling site was assessed and described in terms of habitat diversity, diversity of fish cover and habitat condition. This was done for each sampling point identified at the sampling sites and repeated during each site visit. The mean depth for each sampling point was based on between 10 and 20 random depth measurements in centimetres (depending on the size of the available habitat). Additionally, the following information was recorded:

- Information on pool depth (gauge plate readings)

- Photographic record taken from a set point

- Water quality (in situ measurements of the following variables: water temperature $\left({ }^{\circ} \mathrm{C}\right), \mathrm{pH}$, conductivity $(\mathrm{mS} / \mathrm{m})$,

secchi depth $(\mathrm{cm})$ and percentage oxygen saturation $(\mathrm{mg} / \ell))$

- Survey of the available habitat by means of transects, recording depth, current flow (in $\mathrm{m} / \mathrm{s}$ ), and substrate type.

As part of the $\mathbf{6}^{\text {th }} \mathbf{s t e p}, 11$ fish collections were carried out at each of the 4 sampling sites between March 2006 and October 2007. A variety of fish-collecting methods were applied depending on the habitat type to be sampled:

The deep slow-flowing pools at EWR3 and EWR4 were sampled by using seine and gill netting. A seine net $2 \mathrm{~m}$ deep, $1.5 \mathrm{~m}$ high and $30 \mathrm{~m}$ long, with mesh sizes of $16 \mathrm{~mm}$ for the wings and $5 \mathrm{~mm}$ for the sac was used, with one seine sample consisting of 3 consecutive hauls. Seven gill nets, comprising mesh sizes of $45 \mathrm{~mm}, 57 \mathrm{~mm}, 68 \mathrm{~mm}, 73 \mathrm{~mm}, 93 \mathrm{~mm}, 118 \mathrm{~mm}$, and $150 \mathrm{~mm}$, were lowered at 18:00 in the evening and cleaned at 06:00 the following morning.

Electro-narcosis was applied at the fast shallow, fast-deep, slow-shallow and, where possible, slow-deep habitats. The initial electroshocker, consisting of a wooden handle $100 \mathrm{~cm}$ long, parallel fork $100 \mathrm{~cm}$ in length and with $25 \mathrm{~cm}$ between parallel forks, with copper-cladtips and powered by a $220 \mathrm{~V} \mathrm{AC}, 2 \mathrm{kVA}$ portable Yamaha generator, was replaced with a SAMUS 725G backpack-electroshocker from August 2006 onwards. The original electro-shocker was not very effective at EWR1 due to the

Table 2

A summary of characteristics of the 4 sampling sites selected on the Seekoei River (* only available when surface flow was present at the site. Velocity depth classes defined by the definition of Kleynhans, 1999: Pools, slow $<0.3 \mathrm{~m} / \mathrm{s}$, shallow $<0.5 \mathrm{~m}$; Riffles/runs/rapids, slow $<0.3 \mathrm{~m} / \mathrm{s}$, shallow $<0.3 \mathrm{~m}$ ).

\begin{tabular}{|c|c|c|c|c|c|c|c|c|c|c|}
\hline \multirow[t]{2}{*}{$\begin{array}{l}\text { Sampling } \\
\text { site }\end{array}$} & \multirow[t]{2}{*}{$\begin{array}{l}\text { Macro- } \\
\text { reach }\end{array}$} & \multirow[t]{2}{*}{$\begin{array}{l}\text { Quaternary } \\
\text { catchment }\end{array}$} & \multicolumn{2}{|c|}{ No. of sampling points } & \multirow[t]{2}{*}{$\begin{array}{l}\text { Mean water depth } \\
(\mathrm{cm}) \text { as indicated } \\
\text { by gauge plates }\end{array}$} & \multirow[t]{2}{*}{$\begin{array}{l}\text { Habitat types } \\
\text { sampled }\end{array}$} & \multicolumn{4}{|c|}{$\begin{array}{l}\text { Velocity-depth classes } \\
\text { present (when channel } \\
\text { flow is present) }\end{array}$} \\
\hline & & & Flow present & Flow absent & & & SD & ss & FD & FS \\
\hline EWR1 & 3 & $\mathrm{D} 32 \mathrm{E}$ & 1 & 1 & $82.14 \pm 4.63$ & Pool & $\mathrm{X}$ & $\mathrm{X}$ & & \\
\hline EWR2 & 4 & D32F & 1 & 1 & $80.14 \pm 28.46$ & Pool & $\mathrm{X}$ & $\mathrm{X}$ & & \\
\hline EWR3 & 5 & $\mathrm{D} 32 \mathrm{~J}$ & 6 & 2 & $68.31 \pm 33.91$ & Pool/run*/riffle* & $\mathrm{X}$ & $\mathrm{X}$ & $\mathrm{X}^{*}$ & $\mathrm{X}^{*}$ \\
\hline EWR4 & 5 & $\mathrm{D} 32 \mathrm{~J}$ & 7 & 2 & $67.35 \pm 45.0$ & Pool/riffle* & $\mathrm{X}$ & $\mathrm{X}$ & $\mathrm{X}^{*}$ & $\mathrm{X}^{*}$ \\
\hline
\end{tabular}


high electrical conductivity at the site which caused the power output to exceed the capacity of the generator. (Electrical conductivity readings of up to $271.4 \mathrm{mS} / \mathrm{m}$ were recorded at EWR1.) The duration of sampling was recorded at each sampling site in order to calculate the catch per unit effort (CPUE) and to ensure consistency during repetitive sampling. Sampling time depended on the number of habitats present at each site.

Fish specimens were identified to species level, weighed and the fork length noted. Fish were returned to the river after notes were taken on their general health, as well as the presence of anomalies and external parasites. When there was any doubt of identification the specimens were preserved in a $10 \%$ formalin solution and later identified in the laboratory. Samples were also sent to the Albany Museum (Grahamstown) for verification. Sampling data for each sampling point were kept separate.

In the $7^{\text {th }}$ step, the fish sampling data for each sampling site were transformed to frequency of occurrence ratings (FROCs), where a FROC rating of ' 0 ' can be described as 'fish species absent' and a rating of ' 5 ' as 'fish species present at almost all sites' (see Table 3; Kleynhans, 2008a). The model requires that 3 or more sampling points are sampled per river section. The fish data are then transformed into a FROC rating by the following calculation:

$\mathrm{FROC}=(\mathrm{Nsp} / \mathrm{Ns}) \times 5$

where:

Nsp: Number of sampling points in a river section where a species was sampled

Ns: Number of sampling points sampled in a river section

5: Maximum frequency of occurrence of a species

Due to the fact that the minimum number of sampling points required $(n=3)$ was not always available, cumulative fish data (including all data accrued up to that date) were used to calculate a FRAI score (as suggested by Kleynhans, 2008b). The number of sampling points (Ns) was therefore substituted by the number of sampling repetitions done up to that point in time and the number of sampling points where a species was sampled (Nsp) was substituted by the number of times a species was sampled at a specific sampling point up to that point in time (as indicated in Table 3).

In the $8^{\text {th }}$ step the FRAI model was run to calculate the FRAI scores.

\section{Results and discussion}

\section{Fish distribution}

The expected and observed fish species for each sampling site are presented in Table 3. Species richness increased in a downstream direction with only one species recorded at EWR1 (in the upper Seekoei) and seven species recorded at EWR4 (in the lower section of the river).

River conditions and habitat diversity differed profoundly between sites EWR1 and EWR2 (situated in the upper and middle sections of the catchment) and between EWR3 and EWR4 (both located in the lower part of the catchment). EWR1 and EWR 2 comprised only 2 velocity-depth classes (slow-deep and slow-shallow), compared to the 4 classes (slow-deep, slow-shallow, fast-deep and fast-shallow) present at EWR3 and EWR4. Habitat diversity at EWR3 and EWR4 is, however, reduced when surface flow stops and pools start to isolate as drying continues. Also, in the upper and middle catchment the surface waters are connected for less than $10 \%$ of the time (Hughes, $2008 \mathrm{~b}$ ), resulting in the river consisting of a series of isolated pools. Especially in the upper and lower reaches the low number of species is expected to be correlated with the high number of impoundments which occur upstream and downstream of the site, reducing surface water connectivity and restricting fish movement. EWR1, in the upper reaches of the Seekoei River, was the only site where the water level remained fairly stable (mean=82.14 $\mathrm{cm} \pm 4.63 \mathrm{~cm}$ ). At the other 3 sites the water level showed large fluctuations (see Table 2), representing very unstable environments for fish.

The variability in flow also had a marked impact on species presence, and therefore on species composition and richness, at specific sites. Although the long-term flow record (Fig. 3) indicates that flow is most likely to occur in March each year, the variability within and between years is high (as indicated by this study). For example, the lower reaches of the river 'unexpectedly' experienced flow throughout the winter of 2006 and only started to dry from November 2006. These dry conditions persisted throughout the following summer, autumn and winter, with flow only resuming in September 2007 (also 'unexpectedly'; see Fig. 3). The impact that this variability in flow has on habitat diversity and, therefore, fish species distribution and richness, is clearly illustrated in Table 3 :

- EWR3 species richness was 4, 6, 6 and 1 in the 4 consecutive sampling periods, respectively.

- Only 1 species was present in all 4 periods, only 3 in 3 ( $75 \%$ of the) periods, and 2 species in 2 (50\% of the) periods

- Species also 'swapped around' (e.g. both L. umbratus and C. carpio were present in September/October 2006 and March 2007, but absent in March 2006 and October 2007)

- The point is stressed by the large variation in FROC values (between 1 and 5 where a species was present). Similarly, large variations in species richness (between 3 and 7), FROC values (e.g. between 2 and 5) and species presence/ absence were found at EWR4.

Only Barbus anoplus, a tolerant and widespread pioneer species (Cambray and Bruton, 1984; Skelton, 2001), was found in the upper reaches (EWR1). Considering the site's location in the catchment, the natural low degree of surface water connectivity and the natural high concentration of electrical conductivity (up to $271.4 \mathrm{mS} / \mathrm{m}$ ), B. anoplus was also the only species expected to occur here.

At EWR2 Labeobarbus aeneus was the only expected fish species not recorded. Species composition also varied markedly between samples. Barbus anoplus had the highest frequency of occurrence, while 2 species were only recorded once. This site represented a very unstable environment for fish. The pool's water level varied between $36 \mathrm{~cm}$ in March 2007 (mean depth: $26 \mathrm{~cm}$ ) and $135 \mathrm{~cm}$ in September 2007 (mean depth: $60.85 \mathrm{~cm}$ ). The water level remained above $85 \mathrm{~cm}$ between March and November 2006, whereafter the pool started to dry. Habitat availability was reduced with only a small wetted area $\left(25 \mathrm{~m}^{2}\right)$ left in March 2007.

Two of the species expected at EWR3, Labeobarbus kimberleyensis and Austroglanis sclateri, were never found. Species richness varied most at this site: between 1 (in October 2007) and 6 (in September 2006). The water level varied considerably, dropping from $115 \mathrm{~cm}$ in May 2006 to $15.5 \mathrm{~cm}$ in March 2007. The rapid was dry from December 2006 to March 2007, implying that EWR3 was isolated for 4 months and as a result, 4 of the 6 sampling points at the site could not be sampled during this period. 


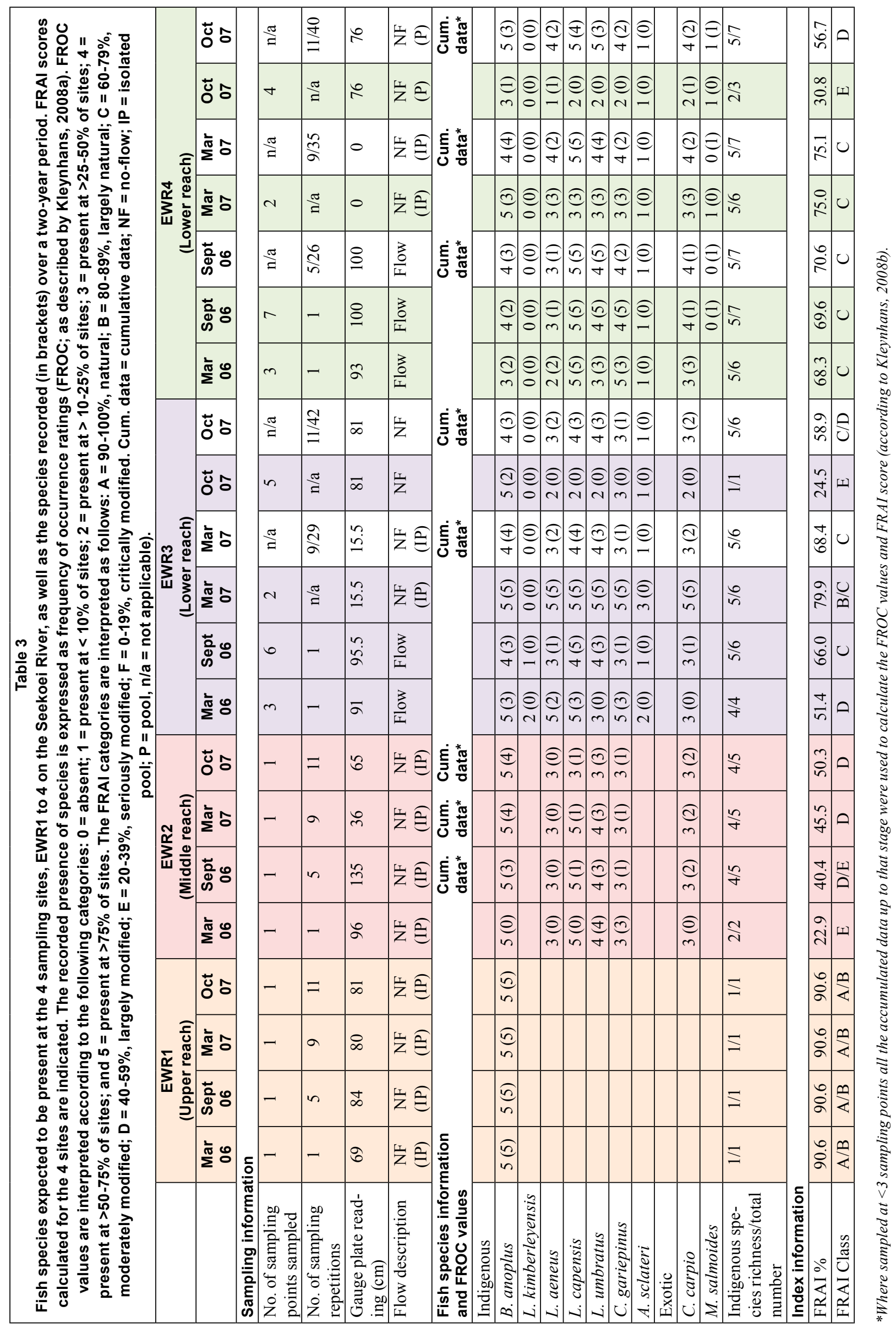


Although EWR4 had the highest overall species richness $(\mathrm{n}=7)$, only 3 species were recorded in October 2007. This followed a 6-month period during which most of the available habitats at the site were dry. During the June 2007 survey, fish were already isolated in a few shallow pools with sandy bottoms and it is most likely that only a few of the larger fish still persisted when flow resumed in October 2007.

\section{The Fish Response Assessment Index (FRAI) as an indication of integrity in the Seekoei River}

For the purpose of presenting a FRAI score the accumulated fish data are shown where fish were sampled at less than 3 sampling points (Table 3). The un-accumulated data for EWR Sites 3 and 4 are shown in order to allow discussion of this point (see later). According to this assessment the ecological integrity in the different sections of the Seekoei catchment varied between natural (Category A) and seriously modified (Category E).

EWR1 in the upper reaches was the most natural site (Category A/B). It was the only site where FRAI values remained constant over the study period. The available habitat, which comprised slow-deep (70\%) and slow-shallow (30\%) velocity-depth classes, remained stable over the 2-year period, sustaining a persistent $B$. anoplus population.

EWR2 showed the highest degree of change, with FRAI increasing from seriously modified (Category E) in March 2006 to largely modified (Category D) in October 2007. This increase was clearly a result of the improved data record and, most probably, not because of improved ecological integrity.

FRAI categories for EWR3 and EWR4 varied between C (moderately modified) and E (seriously modified). FRAI scores at both these sites showed a similar pattern of increase from March 2006 to March 2007, and thereafter dropped markedly in October 2007.

The fact that accumulated data were used to calculate FROC scores potentially influenced the calculations of FRAI scores, leading to possibly incorrect assumptions about the integrity of a river reach. Although it has been suggested that FRAI scores improve with the number of points sampled, it is not always possible to increase the number of sampling points at a site to 3 or more (e.g., when the river stopped flowing in December 2006 the diversity of habitats, and therefore the number of sampling points, at EWR3 and EWR4, was reduced to 2 at each site). Habitat composition changed, which had a marked influence on fish species presence/absence and relative abundance (see, e.g., differences between October 2007 datasets calculated on actual data vs. accumulated data for both sites EWR 3 and 4 - Table 3). The use of accumulated data is, therefore, incorrect under such ephemeral conditions. One must also bear in mind that the catchability of fish in isolated pools differs from that in flowing streams, in that fish density increases due to drying (Magoulick, 2000). Another reason for the change in FRAI scores is that some species (e.g. L. kimberleyensis) are removed from the reference list, as the available habitat (in an isolated pool) is deemed to be unsuitable. It is therefore suggested that FRAI scores in ephemeral rivers should not be calculated using data accumulated under different flow conditions. In this study the differences in FRAI scores, calculated with accumulated data vs. the data for that sampling only, were notable in: March 2007 at EWR3, the difference was almost 1 category (from B/C to C); October 2007 at EWR4, the difference was 1 category (from E to D); and October 2007 at EWR3, the difference was almost 2 categories (from $\mathrm{E}$ to $\mathrm{C} / \mathrm{D}$ ).

\section{Conclusions}

In South Africa the Fish Response Assemblage Index (FRAI) is regarded as a useful tool to indicate biological integrity in most perennial rivers, as well as those non-perennial rivers with higher species richness in the northern parts of South Africa. This study, however, showed how difficult it will be to apply any scoring method on ephemeral rivers in the drier interior and western parts of South Africa, where communities consist of relatively few, hardy, species. Here a high degree of environmental variability, and consequently the continuous, but irregular, loss and gain of habitats, has contributed to the low diversity of indigenous species (see also Grossman, 1982). Man-made weirs and the natural formation of isolated pools add to the loss of system connectivity and prohibit the frequent and immediate re-colonisation of the upper, middle and lower stretches of the Seekoei from the important refugia (see also Sedell et al., 1990; Bramblett and Fausch, 1991; Magoulick, 2000).

The relative absence of historical information on the fish species in these ephemeral rivers further complicates the use of an expected vs. observed species ratio. The low number of species adds to the problem as one species expected but not found, or vice versa, will change scores considerably and impact negatively on the conclusions drawn from the fish assessment. The current scoring methods are, therefore, inappropriate for these species-poor systems.

This study suggest that, for comparative purposes, samples should be taken under the same hydrological conditions, e.g., samples taken when surface flow was present should not be compared to those taken in isolated pools. However, it is nearly impossible to forecast flow connectivity, and difficult to predict how long re-colonisation will take after surface flow is resumed. This situation is further complicated by the fact that re-colonisation time is also influenced by biophysical variables during the specific time of the year when flow is resumed, and the reproductive phase and composition of the various species.

The low species richness and the generalised habitat, trophic and reproductive requirements of the fish species present in the Seekoei River ecosystem further makes it almost impossible to make use of the presence or absence of indicator species as a reference for biological integrity.

The current analysis of our data suggests that a more generalised approach to determine the integrity of fish communities should be considered for the Seekoei and similar rivers in the Orange River system. Community structure characteristics like age classes, species diversity and evenness, assessing the physical condition of individuals (external health; length/mass ratios, etc.) at local level, and the presence/absence of exotic species could provide useful insights into these depauperate fish communities. The next phase of the study will investigate these, as well as the challenges of including these variables under highly variable conditions.

\section{Acknowledgements}

The Water Research Commission is acknowledged for financial support, and the University of the Free State for the use of facilities. J du Plessis, O Scholtz, J Potgieter and T Vos are thanked for their assistance in the field. Prof. M Seaman and Dr $\mathrm{N}$ Avenant are thanked for their advice and support. The two anonymous reviewers are acknowledged and thanked for their contribution to improving the manuscript. 


\section{References}

ACREMAN M and DUNBAR MJ (2004) Defining environmental flow requirements - a review. Hydrol. Earth Syst. Sci. 8 (5) 861-876.

ARTHINGTON AH, RALL JL, KENNARD MJ and PUSEY BJ (2003) Environmental flow requirements of fish in Lesotho rivers using the DRIFT methodology. River Res. Appl. 19 641-666.

BENADE C (1993) Studies on fish populations in the regulated Orange River System within the borders of the Cape Province. M.Sc. dissertation, University of the Free State, Bloemfontein, South Africa.

BENADE C (2006) Personal communication, 23 March 2006. Environmental consultant, Eco-impact CC, Kimberley, South Africa.

BISHOP J (2005) Personal communication, 21 November 2005. Farm owner, Haasfontein, Hanover district, South Africa.

BRAMBLETT RG and FAUSCH KD (1991) Variable fish communities and the index of biotic integrity in a Western Great Plains river. Trans. Am. Fish. Soc. 120 752-769.

BROWN CA and KING JM (2000) Environmental Flow Assessment for Rivers. A Summary of the DRIFT Process. Southern Waters Information Report 01/00. Southern Waters, Cape Town, South Africa.

CAMBRAY JA (2006) Personal communication, 13 March 2006. Curator, Freshwater Ichthyology, Albany Museum, Grahamstown, South Africa.

CAMBRAY JA and BRUTON MN (1984) The reproductive strategy of a barb, Barbus anoplus (Pisces: Cyprinidae). Colonizing a manmade lake in South Africa. J. Zool. 204 143-168.

CLARKE A (2005) Personal communication. Farm owner, Welgedacht, Hanover district, South Africa.

DOLLAR ESJ (2005) Macro-reach analysis for the Seekoei River. In: Seaman MTS, Avenant MF, Watson M, King J, Armour J, Barker CH, Dollar ESJ, du Preez PJ, Hughes DA, Rossouw L and Van Tonder G (eds.) Developing a Method for Determining the Environmental Water Requirements for Non-Perennial Rivers. Final Report to the Steering Committee for WRC Project No. K5/1587, approved 28 September 2009. Water Research Commission, Pretoria, South Africa.

GAIGHER IG, HAMMAN KCD and THORNE SC (1980) Possible adaptive significance of sex ratio and sexual differences in size at maturity in the Orange River Labeo, Labeo capensis. J. Limnol. Soc. S. Afr. 6 (1) 35-38.

GROSSMAN GD (1982) Dynamics and organization of a rocky intertidal fish assemblage: the persistence and resilience of taxocene structure. Am. Nat. 119 611-637.

HOCUTT CH and SKELTON PH (1983) Fishes of the Sak River, South Africa with comments on the nomenclature of the smallmouth yellowfish, Barbus aneus (Burchel, 1822). Special Publication 32, JLB Smith Institute of Ichthyology, Grahamstown, South Africa. 11 pp.

HUGHES DA (2008a) Hydrological Information and Methods to Support the Determination of Environmental Water Requirements in Ephemeral River Systems. WRC Report No. KV 205/08. Water Research Commission, Pretoria, South Africa.

HUGHES DA (2008b) Personal communication, 10 March 2008. Director, Institute for Water Research, Rhodes University, Grahamstown, South Africa.

JUBB RA (1964) Freshwater fishes and drainage basins in southern Africa: 1: The Orange and South Coastal drainage basins. S. Afr. J. Sci. 60 17-21.

JUBB RA (1967) Freshwater Fishes of Southern Africa. Balkema, Cape Town, South Africa.

JUBB RA (1972) The fishes of the Orange River. Civ. Eng. S. Afr. 14 (2) $89-93$

KING J, BROWN C and SABET H (2003) A scenario-based holistic approach to environmental flow assessments for rivers. River Res. Appl. 19 619-639.

KING JM, THARME RE and DE VILLIERS MS (2000) Environmental Flow Assessments for Rivers: Manual for the Building Block Methodology. WRC Report No. TT 131/00, Water Research Commission, Pretoria, South Africa.

KLEYNHANS CJ (1996) A qualitative procedure for the assessment of the habitat integrity status of the Levuvhu River (Limpopo system, South Africa). J. Aquat. Ecosys. Health. 5 41-54.

KLEYNHANS CJ (1999) The development of a fish index to assess the biological integrity of South African rivers. Water SA 25 (3) 265-277.

KLEYNHANS CJ (2003) National Aquatic Ecosystem Biomonitoring Programme (NAEBP): Report on a National Workshop on the use of fish in aquatic system health assessment. NAEBP Report Series No.16. Institute for Water Quality Studies, Department of Water Affairs and Forestry, Pretoria, South Africa.

KLEYNHANS CJ (2008a) Module D: Fish Response Assessment Index in River EcoClassification: Manual for EcoStatus Determination (Version 2). Joint Water Research Commission and Department of Water Affairs and Forestry Report. WRC Report No. TT 330/08. Water Research Commission, Pretoria, South Africa.

KLEYNHANS CJ (2008b) Personal communication, 10 December 2008. Chief Specialist Scientist (River and Fish Ecology), Resource Quality Services, Department of Water Affairs, Pretoria, South Africa.

KLEYNHANS CJ and HILL L (1999) Determination of Resource Quality Objectives for Habitat Integrity. RDM Riv_AppR23Version1.0. Institute of Water Quality Studies. Department of Water Affairs and Forestry, Pretoria, South Africa.

KLEYNHANS CJ and LOUW MD (2008) Module A: EcoClassification and EcoStatus Determination: Manual for EcoStatus Determination (Version 2). Joint Water Research Commission and Department of Water Affairs and Forestry Report. WRC Report No. TT 329/08. Water Research Commission, Pretoria, South Africa.

KLEYNHANS CJ, THIRION C and MOOLMAN J (2004) A Level 1 and II River Ecoregion Classification System for South Africa, Lesotho and Swaziland. Draft Report No. N/0000/00/REQ0104. Resource Quality Services, Department of Water Affairs and Forestry, Pretoria, South Africa.

LOUW MD (2004) Section A: General: EcoClassification and Habitat Flow Stressor Response Manual (First draft, June 2004). Department of Water Affairs and Forestry, Pretoria, South Africa

LOUW MD and HUGHES DA (2002) Resource Directed Measures for Protection of Water Resources: River ecosystems - Revision of a quantity component. Department of Water Affairs and Forestry, Pretoria, South Africa.

MAGOULICK DD (2000) Spatial and temporal variation in fish assemblages of drying stream pools: The role of abiotic and biotic factors. Aquat. Ecol. 34 29-41.

NIEWOUDT TC (2005) Personal communication, 21 November 2005. Farm owner, Vanzylskraal, Hanover District, South Africa.

O'KEEFFE J, HUGHES DA and THARME RE (2002) Linking ecological responses to altered flow, for use in environmental flow assessments: the Flow Stressor-Response method. Verh. Int. Ver. Theor. Angew. Limnol. 28 84-92.

PUSEY BJ (1998) Research and development on methods for freshwater fish. In: Arthington AH, Pusey BJ, Brigza SO, McCosker RO, Bunn SE and Growns IO (eds.) Comparative Evaluation of Environmental Flow Assessment Techniques: R and D Requirements. LWRRDC Occasional Paper 24/98. Land and Water Resources Research and Development Corporation, Canberra, Australia.

SAIAB (South African Institute for Aquatic Biodiversity) (2006) National Fish Collection Database. South African Institute for Aquatic Biodiversity, Grahamstown, South Africa. URL: http:// saiab.ac.za:8080/WebSearchSAIAB/index.jsp (Accessed 28 June 2006).

SCHULTZ BR (1980) Climate of South Africa: Part 8. General survey. Department of Transport, Weather Bureau, Pretoria, South Africa.

SCHULZE RE (1997) South African Atlas of Agrohydrology and Climatology. WRC Report No. TT 82/96. Water Research Commission, Pretoria, South Africa.

SEDELL JR, REEVES GH, HAUER FR, STANFORD JA and HAWKINS CP (1990) Role of refugia in recovery from disturbances: modern fragmented and disconnected river systems. Environ. Manage. 14 (5) 711-724. 
SKELTON PH (1986) Fish of the Orange -Vaal system. In: Davies BR and Walker KF (eds.) The Ecology of River Systems. Dr W. Junk Publishers, Dordrecht, The Netherlands. Monogr. Biol. 60 143-161.

SKELTON PH (2001) Freshwater Fishes of Southern Africa. Struik Publishers, Cape Town, South Africa. 395 pp.

SKELTON PH and CAMBRAY JA (1981) The freshwater fishes of the middle and lower Orange River. Koedoe 24 51-66.

STEŸN EC (2005) Availability and expected quality of hydrological data for the Seekoei River and upper Riet River catchment. Directorate of Hydrological Information. Department of Water Affairs and Forestry, Kimberley, South Africa.

TENNANT DL (1976) Instream flow requirements for fish, wildlife, recreation and related environmental resources. Fish. 16-10.

THARME RE and KING JM (1998) Development of the Building Block Methodology for Instream Flow Assessments, and Supporting Research on the Effects of Different Magnitude Flows on Riverine Ecosystems. WRC Report No. 576/1/98. Water Research Commission, Pretoria, South Africa.

TÓMASSON T, CAMBRAY JA and JACKSON PBN (1984) Reproductive biology of four large riverine fishes (Cyprinidae) in a manmade lake, Orange River, South Africa. Hydrobiol. 112 179-195.
VAN SCHOOR DJ (1972) Relative population densities and breeding habits of fish in the upper Orange River. Civ. Eng. S. Afr. 14 (2) $89-93$.

VAN TONDER G, HUGHES DA and USHER B (2007) Groundwater/ surface water interaction - a new perspective. Paper presented at the Geological Society of South Africa Groundwater Conference, 8-10 October 2007, Ilanga Estate, Bloemfontein, South Africa.

VENTER C (2005) Personal communication, 22 November 2005. Farm owner, Holfontein, Colesberg district, South Africa.

VENTER JM, MOCKE C and DE JAGER JM (1986) Climate. In: Cowling RM, Roux PW and Pieterse AJH (eds.) Karoo Biome: A Preliminary Synthesis. Part 1: Physical Environment. South African National Scientific Programmes Report No. 124, Pretoria. WATSON M and BARKER CH (2006) Habitat Integrity Assessment of the Seekoei River. In: Seaman MTS, Avenant MF, Watson M, King J, Armour J, Barker CH, Dollar ESJ, Du Preez PJ, Hughes DA, Rossouw L and Van Tonder G (eds.) Developing a Method for Determining the Environmental Water Requirements for NonPerennial Rivers. Final Report to the Steering Committee for WRC Project No. K5/1587, approved 28 September 2009. Water Research Commission, Pretoria, South Africa. 
Available on website http://www.wrc.org.za

ISSN 0378-4738 (Print) = Water SA Vol. 36 No. 4 July 2010

ISSN 1816-7950 (On-line) $=$ Water SA Vol. 36 No. 4 July 2010 